\title{
PERBANDINGAN KARAKTERISTIK FISIKOKIMIA ANTARA COCOA BUTTER ALTERNATIVE (CBA) DENGAN LEMAK KAKAO UNTUK PENGEMBANGAN STANDAR NASIONAL INDONESIA \\ Comparison of Characteristic Between Cocoa Butter Alternative (CBA) and Cocoa Butter for Developing Indonesian National Standard
}

\author{
Reno Fitri Hasrini dan Ning Ima Arie Wardayanie \\ Balai Besar Industri Agro (BBIA), Kementerian Perindustrian \\ Jl. Ir. H. Juanda No. 11, Bogor 16122 \\ e-mail: rheefit@yahoo.com
}

Diterima: 6 Desember 2019, Direvisi: 27 Februari 2020, Disetujui: 27 November 2020

\begin{abstract}
Abstrak
Cocoa butter alternative (CBA) atau alternatif lemak kakao memegang peranan penting dalam industri pengolahan cokelat atau konfeksioneri. CBA terdiri dari Cocoa Butter Equivalents (CBE), Cocoa Butter Replacers (CBR), Cocoa Butter Substitutes (CBS) yang terbagi berdasarkan komposisi kimia dan kompatibilitas dengan lemak kakao. Belum ada standar nasional dan internasional yang mengatur dan membedakan karakteristik ketiga produk tersebut. Tujuan penelitian ini adalah untuk mengetahui karakteristik CBE, CBR dan CBS dan dianalisis untuk pengembangan konsep Rancangan Standar Nasional Indonesia (RSNI) Alternatif Lemak Kakao. Metode penelitian adalah sampling dan membeli produk CBE, CBR dan CBS ke industri-industri. Analisis terhadap CBE, CBR dan CBS dilakukan untuk mengetahui karakteristiknya serta membandingkannya dengan SNI 3748:2009 Lemak Kakao. Parameter mutu yang dianalisis adalah titik leleh, kadar air, kadar asam lemak bebas, bilangan peroksida, bilangan iod, dan asam lemak trans. Hasil analisis menunjukkan bahwa CBE, CBR, CBE mempunyai kisaran rerata titik leleh sebesar $18,5-34,11^{\circ} \mathrm{C}$, kadar air $0,12-0,17 \%$, kadar asam lemak bebas $0,06-0,10 \%$, bilangan peroksida $0,21-2,65$ mek $\mathrm{O}_{2} / \mathrm{kg}$, bilangan iod 2,15-38,7 gram $\mathrm{I}_{2} / 100 \mathrm{~g}$, dan asam lemak trans $0,4-0,11 \%$. Parameter titik leleh, kadar air, kadar asam lemak bebas, bilangan peroksida, dan bilangan iod CBE, CBR dan CBS memenuhi semua syarat mutu SNI 3748:2009 Lemak Kakao. Nilai asam lemak trans CBA memenuhi syarat WHO (2010). Konsep RSNI Alternatif Lemak Kakao (CBA) yang diusulkan berdasarkan analisis tersebut adalah titik leleh $32-45^{\circ} \mathrm{C}$ untuk CBR dan CBS, untuk CBE tidak ditetapkan, kadar air maksimum 0,3\%, kadar asam lemak bebas maksimum $0,3 \%$, bilangan peroksida maksimum 3,0 mek $\mathrm{O}_{2} / \mathrm{kg}$, bilangan iod untuk $\mathrm{CBE}$, CBR dan CBS maksimum 40, 60 dan 20 gram I $/ 100$ g berturut-turut.
\end{abstract}

Kata kunci: Cocoa Butter Alternative (CBA), Cocoa Butter Equivalents (CBE), Cocoa Butter Replacers (CBR), Cocoa Butter Substitutes (CBS), syarat mutu

\begin{abstract}
Cocoa butter alternative (CBA) plays an important role in the chocolate or confectionery industries. CBA consists of Cocoa Butter Equivalents (CBE), Cocoa Butter Replacers (CBR), Cocoa Butter Substitutes (CBS) which are divided based on chemical composition and compatibility with cocoa butter. There are currently no national and international standards that require and distinguish the characteristics of the three products. The aim of this study is to understand the characteristics of CBE, CBR and CBS and analyze it in order to develop the concept RSNI for CBA. The quality parameters which consist of melting point, moisture, free fatty acid (FFA), peroxide value (PV), iodine value (IV), and trans fatty acids of CBE, CBR and CBS was analyzed and and compare to SNI 3748:2009 Cocoa Butter. The results showed that CBE, CBR, CBS had melting point range of 18.5-34.11 ${ }^{\circ} \mathrm{C}$, moisture of $0.12-0.17 \%$, ffa of $0.06-0.10 \%$, pv of 0.21-2.65 mek $\mathrm{O}_{2} / \mathrm{kg}$, iv of 2.15-38.7 grams $\mathrm{I}_{2} / 100 \mathrm{~g}$, and trans fatty acids $0.4-0.11 \%$. All of parameters of CBE, CBR and CBS meet the quality requirements of SNI 3748: 2009 Cocoa butter. Except for trans fatty acid values meet WHO requirements (2010). Based on these analyses, the concept of RSNI for CBA are melting point for CBR and CBS of $32-45^{\circ} \mathrm{C}$, but it is not determined for CBE; maximum moisture content of 0.3\%; maximum level for ffa of $0.3 \%$; maximum pv of 3.0 mek $\mathrm{O}_{2} / \mathrm{kg}$; and maximum iv for CBE, CBR and CBS of 40, 60 and 20 grams of $I_{2} / 100 \mathrm{~g}$, respectively.
\end{abstract}

Keywords: Cocoa Butter Alternative (CBA), Cocoa Butter Equivalents (CBE), Cocoa Butter Replacers (CBR), Cocoa Butter Substitutes (CBS), quality requirements 


\section{PENDAHULUAN}

Salah satu industri pangan yang saat ini berkembang pesat adalah industri pangan pengolahan cokelat atau konfeksioneri. Secara garis besar olahan biji kakao (Theobroma cacao) adalah lemak kakao, bubuk kakao dan permen atau produk olahan cokelat yang dalam pengolahannya saling tergantung satu sama lainnya. Sebagian besar lemak kakao digunakan sebagai bahan baku produk olahan cokelat seperti cokelat batangan, cokelat oles (chocolate spread), chocolate coating dan lainlain. Dalam industri konfeksioneri, lemak kakao merupakan bahan baku penting yang berkontribusi terhadap sifat-sifat tekstural dan sensori produk konfeksioneri, khususnya produk-produk cokelat. Lemak kakao merupakan lemak dengan karakteristik fisikokimia yang unik, karena komposisi triasilgliserolnya hampir $80 \%$ didominasi oleh tiga triasilgliserol (TAG) simetrik, saturatedmonounsaturated-saturated, yaitu palmitat-oleatstearat (POS), stearat-oleat-stearat (SOS) dan palmitat-oleat-palmitat (POP) (Wainwright, 1996). Ketika dimakan, lemak kakao meleleh sempurna di mulut dengan tekstur creamy dan suatu sensasi yang menyejukkan (Gunstone, 2002).

Penggunaan lemak kakao dalam produksi cokelat mengalami beberapa permasalahan diantaranya adalah suplai biji kakao sebagai sumber lemak kakao yang tidak menentu, variabilitas dan kualitas yang kurang memadai pada pengolahan lemak kakao, harga yang relatif mahal dan berfluktuasi dibandingkan dengan lemak lainnya serta iklim Indonesia yang tropis sulit untuk menjaga lemak kakao untuk tetap keras di suhu ruang (Fuji Oil Europe, 2004). Sementara di lain pihak permintaan dunia terhadap produk makanan dari cokelat meningkat. Oleh karena itu, berbagai upaya dilakukan untuk mengembangkan specialty fats sebagai altematif penggunaan lemak kakao, salah satunya adalah cocoa butter alternatives (CBA).

CBA atau dikenal dengan hard butter memiliki variasi derajat kesamaan dengan lemak kakao dalam hal sifat pelelehan dan kecenderungan mengkristal (Wainwright, 1996). Berdasarkan komposisi kimia dan kompatibilitas dengan lemak kakao, pengelompokkan CBA dibagi menjadi tiga jenis yaitu (1) Cocoa Butter Equivalents (CBE) adalah lemak nabati non laurat (tidak mengandung asam laurat) yang sifat-sifat fisik dan kimianya mirip dengan lemak kakao dan dapat dicampur dengan lemak kakao pada jumlah berapapun tanpa mengubah sifat- sifat lemak kakao; (2) Cocoa Butter Replacers (CBR) yaitu lemak non laurat dengan distribusi asam lemak mirip lemak kakao, tetapi struktur trigliseridanya berbeda sepenuhnya, hanya pada rasio kecil kompatibel dengan lemak kakao; (3) Cocoa Butter Substitutes (CBS) yang merupakan lemak nabati laurat (mengandung asam laurat), berbeda sepenuhnya dengan lemak kakao secara kimia, dengan beberapa kemiripan sifat fisik, hanya cocok untuk pensubstitusi lemak kakao sampai 100\% (Naik \& Kumar, 2014).

Harga CBA ditentukan oleh fungsionalitasnya, antara lain daya tahan terhadap panas, daya tahan terhadap blooming, kemudahan tempering dan sebagainya. CBE mempunyai fungsionalitas yang paling tinggi diantara ketiga jenis CBA (Gambar 1). Oleh karena itu, CBE mempunyai harga yang paling mahal dan CBS yang paling murah.

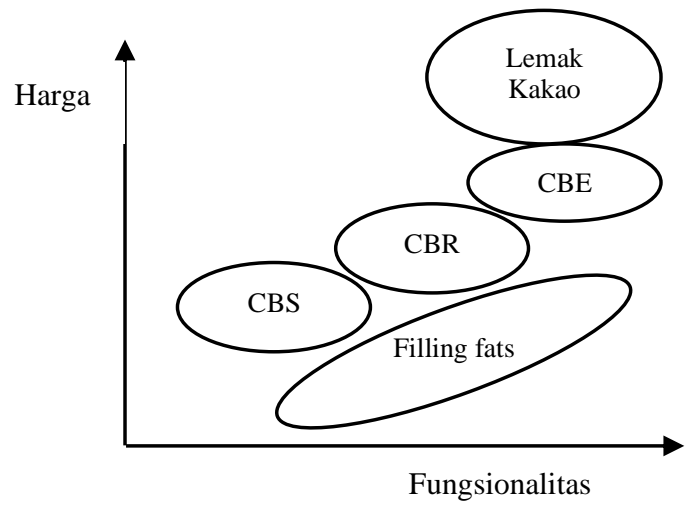

Gambar 1 Hubungan antara harga CBA dengan fungsionalitas (Balle, 2006).

Saat ini CBE, CBR dan CBS sudah sangat banyak digunakan sebagai bahan baku industri konfeksioneri di Indonesia, namun ketiga jenis produk ini memiliki karakteristik fisik, kimia, mutu dan harga yang berbeda. Belum ada standar nasional dan internasional yang mengatur dan membedakan karakteristik ketiga produk tersebut.

Oleh karena itu untuk menghindari pemalsuan dan tercampur aduknya produk $\mathrm{CBE}$, CBR, dan CBS, dibuat pemetaan konsep syarat mutu untuk CBE, CBR dan CBS. Parameter yang dijadikan syarat mutu adalah titik leleh, kadar air, asam lemak bebas, bilangan peroksida, bilangan iod dan asam lemak trans. Tujuan dari penelitian ini adalah untuk mengetahui karakteristik CBE, CBR dan CBS di Indonesia, membandingkan dengan SNI Lemak Kakao dan menetapkan konsep RSNI Alternatif Lemak Kakao. 


\section{TINJAUAN PUSTAKA}

\subsection{Definisi dan Karakteristik Lemak Kakao}

Lemak kakao merupakan lemak alami berwarna kuning terang yang diperoleh dari biji kakao (Theobroma cacao). Menurut Minifie (1999), beberapa negara memberi batasan yang lebih spesifik tentang lemak kakao, yaitu sebagai hasil pengepresan cocoa nib (kotiledon kakao) setelah dipisahkan dari shell (proses winnowing). Lemak kakao bersifat keras dan mudah patah (brittle) di bawah suhu ruang dengan titik leleh $32-35{ }^{\circ} \mathrm{C}$, tetapi ketika dimakan, lemak kakao meleleh sempurna di mulut dengan tekstur creamy yang lembut dan sensasi dingin (Gunstone, 2002).

Polimorfismenya juga berpengaruh besar terhadap sifat-sifat fisik dari produk cokelat, seperti kilap (gloss), derak (snap), kontraksi, ketahanan panas, pelelehan yang cepat dan tajam di mulut, serta ketahanan bloom (Osborn dan Akoh, 2002). Karakteristik tersebut sebagai konsekuensi dari komposisi trigliserida (triasilgliserida/TAG) lemak kakao yang hampir $80 \%$ didominasi oleh tiga TAG simetrik, saturated-unsaturated-saturated (StUSt), yaitu palmitat-oleat-palmitat (POP, $16.8-19.0 \%$ ), palmitat-oleat-stearat (POS, 38.0-43.8\%) dan stearat-oleat-stearat (SOS, 22.8-30.0\%) (Lipp et al. 2001). Lemak kakao juga mengandung sejumlah kecil TAG yang tidak simetrik (POO, PSO dan SSO).

Komposisi TAG yang unik bersama-sama dengan kandungan diasilgliserol (DAG) yang sangat rendah membentuk lemak kakao dengan sifat fisik yang diinginkan dan kemampuannya untuk rekristalisasi selama pengolahan untuk membentuk suatu kristal stabil (Shukla, 2005: Liu, Chang, Liu, 2007). Karakteristik unik tersebut juga menjadi alasan yang membuat lemak kakao dianggap sebagai lemak ideal dan pilihan dalam industri cokelat konfeksioneri, sehingga menciptakan permintaan pasar yang besar melebihi pasokan. Biji kakao mengandung lemak kakao relatif kecil (52.5-55.5\% dari nib). Sementara itu, hanya sedikit negara yang membudidayakan kakao, sehingga suplai menjadi tidak stabil dan harganya relatif paling mahal di antara lemak dan minyak alami (Zaidul et al., 2007)

Menurut Torbica, Jovanovic, \& Pajin (2006), selain pasokan dan harga yang tidak menentu, lemak kakao juga kurang memadai untuk digunakan pada iklim panas serta kualitasnya bervariasi antar wilayah yang berbeda. Selain itu, proses tempering diperlukan untuk produk cokelat yang sepenuhnya menggunakan lemak kakao dalam formulasinya, karena akan cenderung mengalami blooming (Fuji Oil Europe, 2004).

\subsection{Definisi dan karakteristik Cocoa Butter Equivalents (CBE)}

CBE umumnya diformulasi dari minyak yang secara alami mengandung TAG simetrik yang diperoleh dengan cara fraksinasi dari sumber minyak dan lemak yang berasal dari tanaman tropik. Sebagian besar berasal dari tanaman liar yang dikenal sebagai exotic fats (illipe, shea, sal, kokum), kecuali sawit yang dibudidayakan di kebun (Wainwright, 1999). Tidak ada lemak yang dihasilkan secara alami dengan sifat-sifat fisik yang mirip lemak kakao. Masing-masing sumber lemak mempunyai kelebihan dan kekurangan TAG lemak kakao, sehingga semua alternatif lemak kakao dibuat dengan cara pencampuran (blending) dan/atau modifikasi lemak (Osborn dan Akoh, 2002). CBE dapat diformulasi dari fraksi tengah minyak sawit ( $p a l m$ mid fraction, PMF) yang kaya TAG POP dengan exotic fats yang kaya TAG POS dan SOS. Formulasi suatu CBE yang tepat merupakan seni terbesar dalam teknologi lemak (Shukla, 2006).

\subsection{Definisi dan karakteristik Cocoa Butter Replacers (CBR)}

CBR diproduksi dari minyak dan lemak non laurat terhidrogenasi parsial (terutama dari minyak kedelai, biji kapas dan sawit). Profil pelelehannya diperbaiki dengan manipulasi parameter hidrogenasi. CBR atau sering disebut CBS non laurat memiliki sifat-sifat flavor, aroma, kilap dan retensi kilap yang baik serta tidak memerlukan tempering, tetapi cenderung mengalami blooming pada penyimpanan jangka panjang. Walaupun mempunyai kompatibilitas rendah terhadap lemak kakao, tetapi CBR sangat kompatibel dengan lemak non laurat lainnya. CBR cocok untuk enrobing produk bakery (lunak atau berongga). CBR dapat dicampur dengan lemak kakao sampai $20-25 \%$ (basis lemak) jika digunakan sebagai confectionery coating (Shukla, 2005).

\subsection{Definisi dan karakteristik Cocoa Butter Substitute (CBS)}

CBS adalah lemak modifikasi dari asam laurat (La) dan asam miristat (Mi) dengan TAG utama LaLaLa, LaLaMi, dan LaMiMi (Shamsudin, Mohamed \& Nooi, 2006). CBS terutama diproduksi dari lemak laurat seperti minyak kelapa dan minyak inti sawit, walaupun sejumlah kecil dari minyak kedelai terhidrogenasi, biji kapas, sawit dan lemak nonlaurat lainnya juga digunakan. Teknik pengolahannya meliputi hidrogenasi, interesterifikasi dan fraksinasi. CBS tidak memerlukan tempering, cepat mengkristal, 
sifat pelelehan dan pelepasan flavor baik, serta kilap dan retensi kilap baik. CBS tidak kompatibel dengan lemak kakao, toleransinya dengan lemak kakao sampai $6 \%$, sehingga digunakan untuk komponen coating, diformulasi dengan bubuk cokelat. Selain itu, jika terhidrolisis akan memberikan flavor sabun (asam laurat) serta mempunyai toleransi yang rendah terhadap lemak susu (Shukla, 2006).

\subsection{Proses Pembuatan CBA dan Penentuan Syarat Mutu}

Terdapat empat proses modifikasi untuk mengubah karakteristik fisikokimia minyak/ lemak untuk menajdi CBA, yaitu hidrogenasi, fraksinasi, blending, dan interesterifikasi (Idris dan Mat Dian, 2005). Proses-proses modifikasi lemak bertujuan mengubah karakteristik kimia sehingga dapat diperoleh sifat fisik yang diinginkan. Hidrogenasi adalah proses penambahan atom hidrogen pada minyak untuk mengeraskannya sehingga dapat memberikan umur simpan yang panjang (Murano, 2003).

Selain hidrogenasi terdapat proses fraksinasi. Fraksinasi merupakan proses yang dapat membagi minyak menjadi dua bagian yaitu komponen yang memiliki titik leleh lebih tinggi dan komponen dengan titik leleh yang lebih rendah (Murano, 2003). Fraksinasi dapat dilakukan dengan tiga cara, yaitu fraksinasi kering, fraksinasi basah, dan fraksinasi dengan pelarut. Proses modifikasi lemak lainnya yaitu blending yang merupakan pencampuran antara dua lemak dimana sifat lemak yang satu melengkapi sifat lemak yang lainnya sehingga dapat menghasilkan produk sesuai harapan. Untuk memproduksi CBE dapat dilakukan blending antara lemak nabati kaya TAG POP dengan exotic fats yang kaya POS dan SOS. Contoh exotic fat antara lain lemak illipe, lemak sal, shea butter, dan kokum butter (Lipp dan Anklam, 2001). Ketersediaan exotic fats di alam semakin terbatas sehingga menjadikan interesterifikasi sebagai pilihan yang baik bagi proses modifikasi lemak untuk sintesis komponen CBE. Selain itu Akoh dan Moussata (1998) menyebutkan bahwa campuran hasil physical blends memiliki kestabilan oksidatif lebih rendah dari pada campuran hasil interesterifikasi.

Interesterifikasi juga dilihat sebagai alternatif pengganti proses hidrogenasi parsial pada minyak dan lemak (Sundram dan Basiron, 2008). Interesterifikasi adalah proses penyusunan kembali atau kombinasi ulang asam lemak di dalam dan di antara molekulmolekul TAG (Murano, 2003). Interesterifikasi dapat membuat perubahan penting dalam fungsionalitas lemak. Noor Lida et al. (2002) menyatakan bahwa proses interesterifikasi tidak menyebabkan isomerisasi ikatan rangkap pada asam lemak, sehingga tidak mengubah komposisi asam lemak tetapi mengubah profil lemak/minyak.

Berdasarkan poses pergantian asam lemak itu sendiri, interesterifikasi dapat dibagi menjadi tiga kelompok yaitu transesterifikasi, alkoholisis, dan asidolisis (Marangoni dan Narine, 2002). Reaksi interesterifikasi dapat dilakukan secara kimia menggunakan katalis logam alkali atau enzimatis.

Dengan banyaknya jenis proses pembuatan CBA maka akan ada banyak faktorfaktor yang memengaruhi mutu CBA. Syarat mutu yang harus dianalisis adalah kadar air, asam lemak bebas, dan bilangan peroksida. Sedangkan indikator yang membedakan karakteristik fisik dan kimia CBE, CBR, dan CBS adalah titik leleh dan bilangan iod. Syarat mutu lainnya adalah asam lemak trans. Proses hidrogenasi parsial dapat menghasilkan asam lemak trans. Keberadaan asam lemak trans menjadi suatu kekhawatiran karena dapat meningkatkan kadar LDL darah (kolesterol) dan juga dapat menurunkan kadar HDL pada darah (Murano, 2003). Semua faktor-faktor ini perlu dianalisis untuk mengetahui mutu dan karakter CBA.

\section{METODE PENELITIAN}

\subsection{Bahan}

Bahan yang digunakan adalah CBE, CBR dan CBS masing-masing berjumlah 2, 11 dan 7 sampel. Bahan-bahan analisis seperti etanol 95 $\%$,indikator fenolftalein (pp), kalium hidroksida, $\mathrm{KOH}$, asam asetat glasial, isooktan, kalium iodida p.a, natrium tiosulfat, kalium iodat $\left(\mathrm{KIO}_{3}\right)$, serbuk kanji, larutan Wijs, dan iod diperoleh dari E. Merck. Alat-alat analisis seperti pipa kapiler yang berdiameter $1 \mathrm{~mm}$ dan panjang $10 \mathrm{~cm}$, refrigerator (suhu $4-10{ }^{\circ} \mathrm{C}$ ), hot plate, termometer $-10-110^{\circ} \mathrm{C}$, kromatografi gas, neraca analitik dengan ketelitian $0,1 \mathrm{mg}$, pemanas listrik, penangas air, pipet ukur berskala $0,05 \mathrm{~mL}$ atau mikro buret, labu ukur $1.000 \mathrm{~mL}, 100 \mathrm{~mL}$, dan $50 \mathrm{~mL}$, gelas ukur kapasitas $10 \mathrm{~mL}$, dan gelas piala $250 \mathrm{~mL}$.

\subsection{Metode Analisis}

Penelitian ini dilakukan pada bulan April-Juli 2019. Pengujian mutu dilakukan di Laboratorium Pengujian Balai Besar Industri Agro. Parameter mutu yang dianalisis adalah titik leleh, kadar air, asam lemak bebas, bilangan peroksida, bilangan iod dan asam lemak trans. Metode 
analisis titik leleh mengacu kepada ISO 6321:2002 Animal and vegetable fats and oils -Determination of melting point in open capillary tubes (slip point). Kadar air mengikuti AOCS Official Method Ca 2c-25, Moisture and Volatile Matter-Air Oven Method. Kadar asam lemak bebas mengacu ke AOCS Official Method $\mathrm{Ca}$ 5a-40, Free fatty acids. Bilangan iod sesuai sesuai SNI ISO 3961: 2018 Animal and Vegetable Fats and Oils-Determination of lodine Value. Asam lemak trans mengikuti metode IUPAC method 2.301 Preparation of Fatty Acid Methyl Ester.

\section{HASIL DAN PEMBAHASAN}

Parameter yang dianalisis untuk sampel CBE, CBR dan CBS adalah titik leleh, kadar air, asam lemak bebas, bilangan peroksida, bilangan iod dan asam lemak trans. Titik leleh dan bilangan iod merupakan parameter utama yang membedakan karakteristik CBE, CBR dan CBS dalam RSNI Alternatif Lemak Kakao. Sedangkan kadar air, asam lemak bebas, bilangan peroksida dan asam lemak trans menjadi syarat mutu CBE, CBR dan CBS. Hasil analisis akan dibandingkan dengan konsep RSNI Alternatif Lemak Kakao, dan SNI 3748:2009 Lemak Kakao.

\subsection{Titik Leleh}

Hasil analisis titik leleh menunjukkan bahwa rerata titik leleh CBE sebesar 18,5 $\pm 21,78{ }^{\circ} \mathrm{C}$ jauh dibawah titik leleh CBR dan CBS yaitu sebesar 36,77 $\pm 5,64$ dan $34,11 \pm 1,81^{\circ} \mathrm{C}$. Titik leleh CBE juga di bawah lemak kakao yang ditetapkan SNI 3748:2009 antara 31-35 ${ }^{\circ} \mathrm{C}$. Oleh karena itu, titik leleh CBE tidak dipersyaratkan di konsep RSNI Alternatif Lemak Kakao. CBE memiliki titik leleh yang rendah karena komposisi TA-nya paling mirip dengan lemak kakao. Asam lemak utama terkandung dalam CBE adalah asam palmitat, asam stearat, asam oleat, asam linoleat, asam arakidat yang mirip dengan lemak kakao. Sebagian besar CBE adalah dibuat dari campuran berbagai campuran sawit minyak, fraksi minyak sawit, shea, dan illipe, sal dan lemak dari kernel manga, yang mengandung sekitar 40\% 1- palmito, 2-olein, 3sterin gliserol (POS), 27\% dari 1,3 gliserol distearinmonooleate (SOS) dan $21 \%$ dari 1,3 dipalmitin-2-monooleato gliserol (POP) dan jumlah trigliserida minor lain (Undurraga, Markovits, \& Erazo, 2001). Sedangkan CBR umumnya dibuat dari hydrogenated oil, soya oil, rape seed oil, cotton seed oil, ground nut oil, dan palm olein dengan asam lemak utama asam elaidat, asam stearat, asam palmitat, dan asam linoleat serta TAG utama PEE dan SEE. Untuk CBS umunya berasal dari minyak kelapa, minyak inti sawit, medium chain triglyceride (MCT) dengan asam lemak utama asam laurat dan asam miristat serta TAG utama LLL, LLM, LMM (Lipp and Anklam, 1998).

Tabel 1 Syarat mutu Cocoa Butter Equivalents, Cocoa Butter Replacers, Cocoa Butter Substitutes, Konsep RSNI Alternatif Lemak Kakao dan SNI 3748:2009 Lemak Kakao.

\begin{tabular}{|c|c|c|c|c|c|c|c|c|c|}
\hline \multirow[t]{2}{*}{ No } & \multirow[t]{2}{*}{ Parameter } & \multirow{2}{*}{$\begin{array}{l}\text { Cocoa } \\
\text { Butter } \\
\text { Equivalents } \\
(\mathrm{CBE})\end{array}$} & \multirow{2}{*}{$\begin{array}{l}\text { Cocoa } \\
\text { Butter } \\
\text { Replacers } \\
(C B R)\end{array}$} & \multirow{2}{*}{$\begin{array}{l}\text { Cocoa } \\
\text { Butter } \\
\text { Substitutes } \\
\text { (CBS) }\end{array}$} & \multicolumn{3}{|c|}{$\begin{array}{l}\text { Konsep RSNI Alternatif } \\
\text { Lemak Kakao (CBA) }\end{array}$} & \multirow{2}{*}{$\begin{array}{l}\text { SNI } \\
3748: 2009 \\
\text { Lemak } \\
\text { Kakao }\end{array}$} & \multirow{2}{*}{$\begin{array}{l}\text { WHO } \\
(2010 \\
)\end{array}$} \\
\hline & & & & & CBE & CBR & CBS & & \\
\hline 1. & $\begin{array}{l}\text { Titik leleh } \\
\left({ }^{\circ} \mathrm{C}\right)\end{array}$ & $18,5 \pm 21,78$ & $36,77 \pm 5,64$ & $34,11 \pm 1,81$ & TD & $32-45$ & & $31-35$ & - \\
\hline 2. & $\begin{array}{l}\text { Kadar air } \\
(\%)\end{array}$ & $0,12 \pm 0,01$ & $0,13 \pm 0,04$ & $0,17 \pm 0,06$ & \multicolumn{3}{|c|}{ Maks. 0,3 } & Maks. 0,2 & - \\
\hline 3. & $\begin{array}{l}\text { Asam lemak } \\
\text { bebas (\%) }\end{array}$ & $0,06 \pm 0,01$ & $0,10 \pm 0,11$ & $0,08 \pm 0,07$ & \multicolumn{3}{|c|}{ Maks. 0,3 } & Maks. 1,75 & - \\
\hline 4. & $\begin{array}{l}\text { Bilangan } \\
\text { peroksida } \\
\left(\text { mek O}_{2} / \mathrm{kg}\right)\end{array}$ & $2,65 \pm 0,91$ & $1,47 \pm 0,83$ & $0,21 \pm 0,55$ & \multicolumn{3}{|c|}{ Maks. 3,0 } & Maks. 4,0 & - \\
\hline 5. & $\begin{array}{l}\text { Bilangan iod } \\
\text { (gram I } / 2 / 100 \\
\text { g) }\end{array}$ & $32,5 \pm 1,56$ & $38,7 \pm 20,46$ & $2,15 \pm 2,22$ & $\begin{array}{l}\text { maks. } \\
40\end{array}$ & $\begin{array}{l}\text { maks. } \\
60\end{array}$ & $\begin{array}{l}\text { maks. } \\
20\end{array}$ & $33-42$ & - \\
\hline 6. & $\begin{array}{l}\text { Asam lemak } \\
\text { trans (\%) }\end{array}$ & $0,4 \pm 0,01$ & $0,11 \pm 0,06$ & $0,70 \pm 1,06$ & - & - & - & - & $<1 \%$ \\
\hline
\end{tabular}

Keterangan: Rerata \pm standar deviasi

CBE dominan dengan asam lemak tidak jenuh bertitik leleh rendah disbanding dengan CBR dan CBS. Pada beberapa kasus, hubungan kesetimbangan dari campuran TAG murni ditentukan dengan mengukur titik lelehnya, tetapi tidak ada titik leleh tunggal untuk lemak alami yang tersusun dari sejumlah TAG yang berbeda (Zhou dan Hartel, 2006).

Parameter titik leleh ini penting dalam pembedaaan CBE, CBR dan CBS karena yang fungsionalitas $\mathrm{CBE}$ cenderung lebih mudah meleleh dibanding CBR dan CBS seperti lemak 
kakao, sehingga dapat dicampur dalam rasio berapapun tanpa mengubah karakter lemak kakao.

\subsection{Kadar air}

Kadar air CBE, CBR dan CBS dapat dilihat pada Tabel 1 yaitu $0,12 \pm 0,01 ; 0,13 \pm 0,04 ; 0,17 \pm$ $0,06 \%$. Data ini masuk ke syarat mutu kadar air pada SNI 3748:2009 Lemak Kakao yaitu maks. $0,2 \%$. Untuk konsep RSNI Alternatif Lemak Kakao kadar air yang ditentukan adalah maks. $0,3 \%$. Nilai KA ini sedikit lebih tinggi dari SNI 3748:2009 Lemak Kakao karena mempertimbangkan proses pembuatan $\mathrm{CBE}$, CBR dan CBE dengan cara blending fisik, esterifikasi secara kimia, hidrogenasi, fraksinasi kimiawi atau enzimatis atau interesterifikasi enzimatis (Naik dan Kumar, 2014). Semua proses ini akan mengakibatkan kadar air naik.

Kadar air merupakan syarat mutu untuk CBA dimana air merupakan media untuk berlangsungnya proses biokimia seperti pembentukan asam lemak bebas, pemecahan protein, dan hidrolisa karbohidrat yang terkandung pada bahan baku CBE, CBR dan CBS (Daulay dan Kholida, 2018).

Kebutuhan minyak nabati yang digunakan sebagai bahan baku CBA masing-masing berbeda. Perbedaan mutu minyak bahan baku CBA sangat ditentukan oleh banyak faktor. Faktor-faktor tersebut dapat langsung dari sifat pohoninduknya, penanganan pasca panen, atau kesalahan selama proses pengangkutan (Daulay dan Kholida, 2018)

\subsection{Asam Lemak Bebas}

Sampel CBE, CBR dan CBS yang dianalisis memiliki kadar asam lemak bebas $0,06 \pm 0,01$; $0,10 \pm 0,11 ; 0,08 \pm 0,07 \%$, masih jauh dibawah SNI 3748:2009 Lemak Kakao yaitu maks. 1,75 \%. Namun konsep RSNI Alternatif Lemak Kakao (CBA) mengusulkan kadar asam lemak bebas maks. 0,3\%, hal ini mempertimbangkan bahwa dalam proses pembuatan CBE, CBR dan CBS yang menggunakan panas otomatis akan menaikkan kadar asam lemak bebas pada produk.

Kenaikan asam lemak bebas ini berkorelasi positif dengan kadar air. Hal ini disebabkan adanya reaksi hidrolisis pada minyak. Hidrolisis yaitu reaksi yang memisahkan asam lemak dari gliserol pada molekul lipid (TAG) akibat adanya molekul air (Murano, 2003). Hasil reaksi hidrolisis minyak sawit adalah gliserol dan asam lemak bebas. Reaksi ini akan dipercepat dengan adanya faktor-faktor panas, air, keasaman, dan katalis (enzim). Semakin lama reaksi ini berlangsung, maka semakin banyak kadar asam lemak bebas yang terbentuk (Daulay dan Kholida, 2018).

\subsection{Bilangan Peroksida}

Hasil analisis bilangan peroksida CBE, CBR dan CBS sebesar $2,65 \pm 0,91 ; 1,47 \pm 0,83 ; 0.21 \pm$ 0,55 mek $\mathrm{O}_{2} / \mathrm{kg}$ dapat dilihat pada Tabel 1. Nilai ini jauh dibawah syarat mutu bilangan peroksida pada SNI 3748:2009 Lemak Kakao yaitu maks. 4,0 mek $\mathrm{O}_{2} / \mathrm{kg}$, sedangkan syarat mutu bilangan peroksida yang diusulkan untuk Konsep RSNI Alternatif Lemak Kakao (CBA) adalah maks. 3,0 mek $\mathrm{O}_{2} / \mathrm{kg}$. Nilai syarat mutu bilangan peroksida Konsep RSNI Alternatif Lemak Kakao (CBA) diusulkan lebih rendah daripada SNI 3748:2009 Lemak Kakao untuk mempertimbangkan masa penyimpanan CBA sebelum diolah menjadi cokelat compound dan mempertimbangkan proses pengolahan CBA menjadi cokelat dengan teknik pemanasan dan pengadukan yang akan terpapar dengan panas dan oksigen, diperkirakan bilangan peroksida akan naik selama proses pengolahan tersebut.

Bilangan peroksida menggambarkan proses oksidasi yang distimulir oleh panas dan oksigen. Oksidasi minyak dan lemak menyebabkan minyak menjadi tengik sehingga disebut dengan ketengikan oksidatif. Ketengikan oksidatif merupakan kerusakan yang paling banyak terjadi pada bahan pangan berlemak yang asam lemaknya teroksidasi oleh oksigen dari udara. Kecepatan ketengikan oksidatif dipengaruhi oleh jumlah ikatan rangkap dari asam lemak tak jenuh. Setiap 1 ikatan tidak jenuh dapat mengabsorbsi 2 atom oksigen, sehingga terbentuk persenyawaan peroksida yang bersifat labil. Peroksida labil ini dapat membentuk senyawa dihidroksi atau turunan dari alfa hidroksi keton. Senyawa yang terbentuk akan memberikan aroma tengik pada minyak dan hilangnya ikatan tak jenuh menjadi jenuh (Famobuwa et al., 2016).

Kerusakan minyak dan lemak sebagai bahan baku CBA selama proses modifikasi minyak dan lemak tersebut akan mempengaruhi mutu dan nilai gizi dari cokelat compound. CBA dengan bilangan peroksida yang tinggi akan menghasilkan cokelat compound dengan cita rasa yang tidak enak serta kerusakan sebagian vitamin dan asam lemak esensial yang terdapat dalam CBA.

Bilangan peroksida juga menggambarkan kemampuan CBA untuk menghasilkan cokelat compound yang memiliki daya tahan dan daya simpan yang lama. Angka oksidasi dihitung berdasarkan angka peroksida. Sebagai standar umum dipakai angka 10 meq (milligram equivalent), tetapi ada yang memakai standar lebih ketat lagi yaitu 6 meq. Di atas angka 
tersebut mutu barang jadi yang dihasilkan dapat dipastikan kurang baik (Daulay dan Kholida, 2018).

\subsection{Bilangan lod}

Bilangan iod pada sampel CBE, CBR, CBS dapat dilihat pada Tabel 1 yaitu sebesar $32,5 \pm$ 1,56; 38,7 $\pm 20,46 ; 2.15 \pm 2,22$ gram I2/100 g. Nilai bilangan iod CBE di bawah bilangan iod SNI 3748:2009 Lemak Kakao yaitu 33-42 gram $\mathrm{I}_{2} / 100 \mathrm{~g}$, nilai CBR masuk ke dalam selang bilangan iod SNI 3748:2009 Lemak Kakao, sedangkan bilangan iod CBS jauh di bawah bilangan iod SNI 3748:2009 Lemak Kakao. Berdasarkan hasil uji produk dan pendapat industri CBE, CBR, dan CBS, nilai bilangan iod yang diusulkan untuk Konsep RSNI Alternatif Lemak Kakao (CBA) adalah maks. 40 gram $\mathrm{I}_{2} / 100 \mathrm{~g}$ untuk CBE, maks. 60 gram $\mathrm{I}_{2} / 100 \mathrm{~g}$ untuk CBR, dan maks. 20 gram $\mathrm{I}_{2} / 100 \mathrm{~g}$.

Bilangan iod adalah jumlah (gram) iod yang dapat diserap oleh 100 gram minyak. Bilangan iod dapat menyatakan derajat ketidakjenuhan dari minyak atau lemak. Semakin besar bilangan iod maka derajat ketidakjenuhan semakin tinggi. Asam lemak yang tidak jenuh dalam minyak dan lemak mampu menyerap sejumlah iod dan membentuk senyawa yang jenuh. Besarnya jumlah iod yang diserap menunjukkan banyaknya ikatan rangkap atau ikatan tidak jenuh (Famobuwa et al., 2016).

Kepadatan lemak digambarkan oleh bilangan iod, semakin tinggi bilangan iod maka ikatan rangkap semakin tinggi dan semakin rendah titik leleh minyak tersebut. Penurunan bilangan iod terjadi apabila molekul hidrogen termigrasi ke dalam karbon sehingga menyebabkan asam lemak menjadi jenuh. Perbedaan bilangan iod pada sampel CBE, CBR dan CBS bisa ditentukan dari awal pada saat proses pembuatan CBE, CBR dan CBS dengan proses yaitu hidrogenasi, fraksinasi, blending, dan interesterifikasi (Idris dan Mat Dian, 2005). Hidrogenasi akan merubah titik leleh dan kandungan lemak padat menjadi lebih tinggi, sedangkan bilangan iod menjadi lebih rendah (Hasibuan, 2009). Perbedaan bilangan iod yang dibuat pada saat pengolahan antara CBE, CBR dan CBS lebih ditujukan agar mudah dblending dengan lemak kakao dan mempunyai kompatibilitas dengan lemak kakao sesuai dengan definisi dan karakteristik dari tiap produk.

\subsection{Asam Lemak Trans}

Kadar asam lemak trans pada sampel CBE, CBR dan CBS sebesar 0,4 $\pm 0,01 ; 0,11 \pm 0,06$; $0.70 \pm 1,06 \%$, nilai ini dibawah persyaratan kandungan asam lemak trans dari WHO (2010) yaitu dibawah 1\%. Asam lemak adalah asam monokarboksilat berantai lurus hasil hidrolisis trigliserida, bersifat jenuh dan tak jenuh berdasarkan ada tidaknya ikatan rangkap rantai karbon di dalam molekulnya. Asam lemak tidak jenuh (memiliki ikatan rangkap) yang terdapat di dalam minyak dapat berada dalam dua bentuk yakni isomer cis dan trans. Asam lemak tak jenuh alami biasanya berada sebagai asam lemak cis, hanya sedikit bentuk trans.

Jumlah asam lemak trans (trans fatty acids = TFA) dapat meningkat di dalam makanan berlemak akibat dari proses pengolahan dan pemanasan pada suhu tinggi seperti hidrogenasi (Silalahi dan Tampubolon, 2012). Pembentukan asam lemak trans terjadi karena masuknya molekul hidrogen ke dalam molekul diena (ikatan rangkap dua) pada posisi yang berseberangan (O'Brien, 2004; Ojieh et al., 2009; dan Singh, Rezac, \& Pfromm, 2009). Selain proses hidrogenasi, TFA juga terbentuk selama pengolahan minyak (refinery) dan menggoreng (deep frying)

Konsumsi TFA menimbulkan pengaruh negatif karena menaikkan kadar LDL, sama seperti pengaruh dari asam lemak jenuh. Akan tetapi disamping menaikkan LDL, TFA juga akan menurunkan HDL sedangkan asam lemak jenuh tidak akan mempengaruhi kadar HDL. Tambahan lagi, TFA cenderung menaikkan lipoprotein aterogenik yakni lipoprotein (a) (Sundram, et al., 1997; Wardlaw and Kessel, 1996; Mancini et al., 2015). Jadi pengaruh TFA dibandingkan dengan asam lemak jenuh, efek negatif dari TFA dapat menjadi lebih dua kali lipat atau lebih daripada pengaruh asam lemak jenuh atau kolesterol yang tinggi (Ovesen, et al. 1998; Subbaiah, Subramanian, \& Liu,1998).

\section{KESIMPULAN}

Cocoa Butter Equivalents (CBE), Cocoa Butter Replacers (CBR) dan Cocoa Butter Substitutes (CBE) memiliki karakteristik fisikokimia yang berbeda satu sama lain. Berdasarkan hal tersebut maka disusun konsep RSNI Alternatif Lemak Kakao (CBA) dengan syarat mutu titik leleh $32-45^{\circ} \mathrm{C}$ untuk CBR dan CBS, untuk CBE tidak ditetapkan, kadar air maksimum 0,3\%, kadar asam lemak bebas maksimum 0,3\%, bilangan peroksida maksimum 3,0 mek $\mathrm{O}_{2} / \mathrm{kg}$, bilangan iod untuk CBE, CBR dan CBS maksimum 40, 60 dan 20 gram $I_{2} / 100$ g berturutturut. 


\section{UCAPAN TERIMAKASIH}

Penulis mengucapkan terimakasih kepada Subdirektorat Direktorat Industri Pengolahan Hasil Perkebunan, Direktorat Industri Makanan Hasil Laut dan Perikanan, Direktorat Jenderal Industri Agro, Kementerian Perindustrian yang telah mendanai analisis produk Cocoa Butter Alternatives (CBA) ini. Ucapan terimakasih juga kami sampaikan kepada pihak-pihak yang mendukung penelitian ini.

\section{DAFTAR PUSTAKA}

Akoh, C. C., \& Moussata, C. O. (1998). Lipase-catalyzed modification of borage oil: incorporation of capric and eicosapentaenoic acids to form structured lipids. Journal of the American Oil Chemists' Society, 75(6), 697-701.

AOCS. (2016). AOCS official method ca 2c-25, moisture and volatile matter-air oven method in official methods and recommended practices of the aocs 7th edition, Urbana, Illinois.

AOCS. (2016). AOCS official method ca 5a-40, free fatty acids in official methods and recommended practices of the aocs 7th edition, Urbana, Illinois.

Badan Standardisasi Nasional. (2009). SNI 3748:2009. Lemak kakao, Jakarta.

Balle J. (2006). Business area chocolate and confectionery fats. Capital Market Day, October 3, 2006.

Daulay, Nur Kholida. (2018). Penentuan kadar air, kadar kotoran, dan kadar asam lemak bebas $(A L B)$ dari inti sawit produksi ptpn iv medan. departemen kimia. Universitas Sumatera Utara.

Famobuwa OE, Oloyede HO, Agbowuro AA. (2016). Chemical Changes in Crude PalmOil and Refined Palm Kernel-Oil Employed in Deep-Frying. The Pharmaceutical and Chemical Journal, 3(3):1-7.

Fuji Oil Europe. (2004). Confectionery. Retrieved from http://www.fujioileurope.com/Products/Conf ectionarv choccoat.htm [15 Juli 2012].

Gunstone, F. D. (2002). Food Applications of Lipids. Di dalam CC Akoh, and DB Min (eds). Food Lipids Chemisty, Nutrition, and Biotechnology. Revised and Expanded.

Hasibuan, H. A. (2009). Perolehan Kembali Nikel dari Katalis Nikel Terpakai (Spent Catalyst) Pasca Proses Hidrogenasi Minyak
Sawit dengan Proses Pelindian (Leaching) Asam Sulfat (Master's thesis).

Idris, N. A., \& Dian, N. L. H. M. (2005). Interesterified palm products as alternatives to hydrogenation. Asia Pacific journal of clinical nutrition, 14(4), 396-401.

ISO 6321:2002 (2002). Animal and vegetable fats and oils -- Determination of melting point in open capillary tubes (slip point)

IUPAC. (1987). Standard method 2.301, preparation of fatty acid methyl ester, in standard methods for analysis of oils, fats and derivatives. 7th Edition, Blackwell, Oxford.

Lipp, M., Simoneau, C., Ulberth, F., Anklam, E., Crews, C., Brereton, P., ... \& Wiedmaier, C. (2001). Composition of genuine cocoa butter and cocoa butter equivalents. Journal of Food Composition and analysis, 14(4), 399-408.

Lipp, M., \& Anklam, E. (1998). Review on cocoa butter and alternatives for use in chocolate. Part B: Method of analysis. Journal of Food Chemistry, 62(1), 73-97.

Liu KJ, Chang HM, Liu KM. (2007). Enzymatic synthesis of cocoa butter analog through interesterification of lard and tristearin in supercritical carbon dioxide by lipase. Food Chemistry 100:1303-1311.

Marangoni, A. G., \& Narine, S. S. (2002). Identifying key structural indicators of mechanical strength in networks of fat crystals. Food Research International, 35(10), 957-969.

Minifie, B. W. (1999). Chocolate, Cocoa and Confectionery : Science and Technology. Gaithersburg: Aspen Publishers, Inc.

Murano, P. S. (2003). Understanding food science and technology (No. 04; TP370, M8.). Thomson/Wadsworth.

Naik, B., \& Kumar, V. (2014). Cocoa butter and its alterna-tives-a review. $J$ Bioresource Eng Technol, 2, 1-11.

Lida, H. N., Sundram, K., Siew, W. L., Aminah, A., \& Mamot, S. (2002). TAG composition and solid fat content of palm oil, sunflower oil, and palm kernel olein belends before and after chemical interesterification. Journal of the American Oil Chemists' Society, 79(11), 1137-1144.

O'brien, R. D. (2008). Fats and oils: formulating and processing for applications. CRC press.

Ojieh, G. C., Idokpesi, G. O., Eidangbe, G. O., Omage, K., \& Oluba, O. M. (2009). 
Hydrogenation impairs the hypolipidemic and antioxidant effects of palm oil in rats. International Journal of Physical Sciences, 4(7), 407-411.

Osborn, H. T., \& Akoh, C. C. (2002). Enzymatically modified beef tallow as a substitute for cocoa butter. Journal of food science, 67(7), 2480-2485.

Ovesen, L., Leth, T., \& Hansen, K. (1998). Fatty acid composition and contents of trans monounsaturated fatty acids in frying fats, and in margarines and shortenings marketed in Denmark. Journal of the American Oil Chemists' Society, 75(9), 1079-1083.

Shamsudin, R., Mohamed, I. O., \& Nooi, T. S. (2006). Rheological properties of cocoa butter substitute (CBS): effects of temperature and characteristics of fatty acids on viscocity. Journal of Food Lipids, 13(4), 402-410.

Shukla, V. K. (2005). Cocoa butter, cocoa butter equivalents, and cocoa butter substitutes. In Handbook of functional lipids (pp. 284312). CRC Press.

Silalahi, J dan S.D.R. Tampubolon. (2012). Asam lemak trans dalam makanan dan pengaruhnya terhadap kesehatan. Jurnal.Teknol. dan Industri Pangan, XIII(2): 184-188.

Singh, D., Rezac, M. E., \& Pfromm, P. H. (2009). Partial hydrogenation of soybean oil with minimal trans fat production using a Ptdecorated polymeric membrane reactor. Journal of the American Oil Chemists' Society, 86(1), 93.

SNI ISO 3961, Lemak dan minyak nabati dan hewani - Penentuan bilangan iod

Subbaiah, P. V., Subramanian, V. S., \& Liu, M. (1998). Trans unsaturated fatty acids inhibit lecithin: cholesterol acyltransferase and alter its positional specificity. Journal of lipid research, 39(7), 1438-1447.

Sundram, K., Ismail, A., Hayes, K. C., Jeyamalar, R., \& Pathmanathan, R. (1997). Trans (elaidic) fatty acids adversely affect the lipoprotein profile relative to specific saturated fatty acids in humans. The Journal of nutrition, 127(3), 514S-520S.

Sundram, K., \& Basiron, Y. (2008). The trans fat dilemma: health VS functionality. Report of the Malaysian Palm Oil Council's Official Report, 3.

Torbica, A., Jovanovic, O., \& Pajin, B. (2006). The advantages of solid fat content determination in cocoa butter and cocoa butter equivalents by the Karlshamns method. European Food Research and Technology, 222(3-4), 385-391.

Undurraga, D., Markovits, A., \& Erazo, S. (2001). Cocoa butter equivalent through enzymic interesterification of palm oil midfraction. Process biochemistry, 36(10), 933-939.

Wainwright, B. (1999). Specialty Fats and Oils. Di dalam N. Widlak (ed). Physical Properties of Fats, Oils and Emulsifiers. Am. Oil Chem. Soc. Press, Champaign, Illinois.

Wainwright, R. E. (1996). Oils and Fats in Confection. Di dalam YH Hui (ed.) Bailey's Industrial Oil and Fat Products. Volume 3 Edible Oil and Fat Products: Products and Application Technology.

Wardlaw, G. M., \& Insel, P. M. (1996). Perspectives in nutrition. Mosby College Pub.

[WHO] World Health Organization and [FAO] Agriculture Organization. (2010). Fats and fatty acids in human nutrition report and expert consultation. In Food and nutrition paper. Vol. 91. Food and Agriculture Organization of the United Nations

Zaidul, I. S. M., Norulaini, N. N., Omar, A. M., \& Smith Jr, R. L. (2007). Blending of supercritical carbon dioxide (SC-CO2) extracted palm kernel oil fractions and palm oil to obtain cocoa butter replacers. Journal of Food Engineering, 78(4), 1397-1409.

Zhou, Y., \& Hartel, R. W. (2006). Phase behavior of model lipid systems: Solubility of high-melting fats in low-melting fats. Journal of the American Oil Chemists' Society, 83(6), 505-511. 
